\title{
Neuromedin-B Receptor
}

National Cancer Institute

\section{Source}

National Cancer Institute. Neuromedin-B Receptor. NCI Thesaurus. Code C28564.

Neuromedin-B receptor (390 aa, $43 \mathrm{kDa}$ ) is encoded by the human NMBR gene. This protein is involved in both peptide hormone binding and $\mathrm{G}$ protein-coupled receptor signaling. 